\title{
Benefit of composting application over landfill on municipal solid waste management in Phnom Penh, Cambodia
}

\author{
B. Seng ${ }^{1} \&$ H. Kaneko ${ }^{2}$ \\ ${ }^{1}$ International Research Center for River Basin Environment, \\ University of Yamanashi, Japan \\ ${ }^{2}$ Interdisciplinary Graduate School of Medicine and Engineering, \\ University of Yamanashi, Japan
}

\begin{abstract}
This paper presents an insight into benefits of organic waste recycling through composting over landfill on municipal solid waste management in Phnom Penh, in terms of greenhouse gases (GHGs) mitigation. Future waste generation from 2003 to 2020 was forecasted and four scenarios of organic waste recycling were carried out. Organic waste-food and garden waste-were used for composting and the remaining waste was landfilled. The recycling scenarios were set based on organic waste generated from difference sources; scenario 1: no recycling, scenario 2: household organic waste; scenario 3: market, restaurant, school and hotel organic waste, and scenario 4: all generated organic waste. The results showed that MSW generation in MPP increased significantly from about 0.24 million ton in 2003 to 0.41 million ton in 2010 and was projected to reach 1.02 million tons in 2020. Composting gave better benefit than landfill. It could reduce GHGs emission of $36.2 \%, 12.8 \%$ and $65.0 \%$ from scenario 2 , scenario 3 and scenario 4 compared with scenario 1 (all generated waste is landfilled), respectively. These percentages reflect the amount of GHGs emission of 3.23, 1.14 and 5.79 million tons $\mathrm{CO}_{2}$ eq from the above respective scenarios. Hence, composting could be a potential GHGs mitigation option for MPP.

Keywords: composting, GHGs, GHG inventory, scenario analysis, solid waste management, Phnom Penh, Cambodia.
\end{abstract}




\section{Introduction}

Cambodia is one of the least developed countries in Southeast Asia with a total population of about 13.39 million people and average gross domestic product (GDP) per capita of about USD 739 in 2008 [1]. In the context of climate change, Cambodia ratified the UN Framework Convention on Climate Change (UNFCCC) in 1995 and acceded to the Kyoto Protocol in 2002. Cambodia has committed to prepare its national greenhouse gases (GHGs) inventory and to identify the possibility of GHGs mitigation options.

In Cambodia, GHGs emission from waste was the third largest amongst the five components - energy, agriculture, land use change and forestry, waste, and industrial process. It was also reported to less significant change from 1994 to 2000; being $273 \mathrm{Gg} \mathrm{CO}_{2 \mathrm{eq}}$ in 1994 and $229 \mathrm{Gg} \mathrm{CO}_{2 \mathrm{eq}}$ in 2000 [2]. Although GHGs emission from waste was seen to decrease, the inventory procedure was conducted differently. It was hence not clear whether the net GHGs emission from waste decreased or increased. However, in conjunction with the creation of economic growth, vast population increase, urbanization, industrialization and excessive consumption of modern daily life, a large quantity of waste would be generated. It was consequently expected to increase in GHGs emission in the later years.

Municipality of Phnom Penh (MPP), capital city of Cambodia, produces a large quantity of municipal solid waste (MSW) which has increased rapidly from 0.136 million tons in 1995 to 0.409 million tons in 2010 [3, 4]. The generated waste has been mainly disposed of at landfill which has been operated in neither sanitary nor environmental sounds. It has been operated with no or irregular soil cover, no leachate treatment facility, no landfill gas capturing facility and hundreds of waste scavengers making their living on the disposal site [5]. MSW generated in MPP comprises a large portion of organic waste with high moisture content. This makes it inevitable to produce $\mathrm{CH}_{4}$ and other gases which potentially contribute to climate change.

Composting of organic waste is one of the potential mitigation options to tackle climate change in Cambodia [6]. Generated waste in MPP contributed $80 \%$ to total urban waste generation [6] and its characteristics are suitable for composting. Hence, the aim of this study is to give an insight into benefit of organic waste recycling through composting, in terms of GHGs mitigation. Future waste generation by 2020 was forecasted and a set of scenario analysis on organic waste recycling were carried out.

\section{Method}

\subsection{Study area}

The study was conducted in MPP, the capital city of Cambodia. MPP has a total area of about $678.46 \mathrm{~km}^{2}$ in 2010 [7]. The entire area is divided into 8 districts and 96 communes. The total population in 2008 was around 1.3 million people with an average population density of 4571 person $\mathrm{km}^{-2}$ and an average household size of 5.1 [1]. 


\subsection{Data collection}

The data describing the quantities of MSW, population and GDP cover from 1994 to 2010. The data of waste generation was collected from three available sources; the Ministry of Environment (MoE), Japan International Cooperation Agency (JICA), and a published paper [8]. The population data was collected from the National Institute of Statistics (NIS), Ministry of Planning (MoP) and GDP data was collected from both NIS and Asian Development Bank (ADB). The other related information, i.e., environmental law, and solid waste regulation and announcements, were collected from $\mathrm{MoE}$ and the Department of Environment of MPP, whereas the overall technical arrangement of MSW management (MSWM) was done through interview the key informants of CINTRI, private firm responsible for collection service, and Phnom Penh Waste Management (PPWM), the responsible authority of SWM in MPP.

\subsection{Scenario set-up}

Four scenarios of organic waste recycling via composting were set up based on sources of waste generation. Generated waste was classified into 9 categories; household, commercial (restaurants), commercial (other shops), market, school, hotel, office, street sweeping and other. The generated waste from every category was basically a mixed waste consisting of both compostable and noncompostable materials. In this study, kitchen and grass/wood waste was considered to be compostable, whereas metals, rubber/leather, textile, bottles/glass, soil/stone, papers and plastics were considered to be noncompostable. Hence, the scenarios were set as the following:

- Scenario 1 (S1) : All generated waste is landfilled (case: current situation).

- Scenario 2 (S2) : Household waste is used for composting while the remaining waste is landfilled (case: The biggest portion of organic waste generation source was recycled).

- Scenario 3 (S3) : Market, restaurant, school and hotel waste is used for composting while the remaining waste is landfilled (case: easy to request for cooperation from the business owners).

- Scenario 4 (S4) : All generated waste is used for composting (case: ideal condition).

\subsection{MSW generation and its composition forecasting}

The data of waste generation was collected from three available sources from 1994 to 2010 . However, the data was neither consistent nor reliable which made it difficult to use for future waste generation forecasting. In this study, hence, the amount of future waste generation was forecasted based on number of generation sources, i.e., household (population), market (number of stalls), restaurant (number of restaurants), etc., and their individual discharge rate. The waste composition was forecasted based on economic growth. The detail of waste generation and its composition forecasts are given as the following: 


\subsubsection{Population}

The population data from 2003 to 2008 was adopted from NIS of Cambodia [1] and from 2009 to 2020 was adopted from Statistics Bureau under Ministry of Internal Affairs and Communications, Japan [9]. The average annual growth rate from 2003 to 2008 was calculated based on the data of General Population Census of Cambodia (GPCC) in 1998, Cambodia Inter-censal Population Survey (CIPS) in 2004 and GPCC in 2008, whereas that from 2009 to 2020 was adopted from the data of a joint study on population projection in Cambodia from 2008 to 2030 of Statistics Bureau, Japan, and NIS, Cambodia.

\subsubsection{Number of waste generation sources}

Number of waste generation sources was forecasted to increase in proportion with the growth rate of GDP. The annual growth rate of GDP was adopted from ADB from 2003 to 2010 [10, 11]. The growth rate after 2010 was assumed to be same as the growth rate in 2010 .

\subsubsection{Waste discharge rate}

Waste discharge rate prediction is practically difficult. It is affected by a number of factors such as business type and size, family income, people behavior, regulation and other factors. To simplify the complexity of effects from these factors, GDP was used as a sole parameter to estimate the discharge rate. The rate of every generation source, hence, was predicted to increase in proportion with the growth of GDP per capita. Based on Japanese statistics on waste generation and economic development from 1963 to 1970, the growth rate was adopted at 50\% of GDP growth rate per capita [5] as the following - 2003-2005: 1.85\% $\mathrm{y}^{-1} ; 2006-2010: 2.30 \% \mathrm{y}^{-1} ; 2011-2020: 1.90 \% \mathrm{y}^{-1}$.

The above annual waste discharge rate will not apply to public cleansing services such as street sweeping and cleaning parks but their amount will be implicitly increased in accordance with the growth of the population and expansion of the city.

\subsubsection{Waste composition forecast}

The waste composition was forecasted based on two assumptions:

- Significant changes in dietary habit and living environment is not anticipated. Therefore, the discharge amount of kitchen waste, garden waste, textile, rubber/leather, soil and stone, and metals were assumed to remain the same.

- The discharge amount of waste for wrapping, i.e., paper, plastics, and bottle and glass were assumed to increase in accordance with economic growth.

\subsection{Greenhouse gases emission}

\subsubsection{Composting}

The GHGs $-\mathrm{CO}_{2}, \mathrm{CH}_{4}, \mathrm{~N}_{2} \mathrm{O}$ - emission from composting process was estimated based on mass balance of $\mathrm{C}$ and $\mathrm{N}$ in the process cycle [12]. $\mathrm{CO}_{2}$ and $\mathrm{CH}_{4}$ can be estimated based on either percent carbon lost or carbon input. In this study, $\mathrm{CO}_{2}$ was estimated based on percent carbon input while $\mathrm{CH}_{4}$ was estimated based on 
percent degraded carbon. The emission of the two gases is expressed as the following:

$$
\begin{gathered}
\mathrm{CO}_{2, \text { release }}=C_{\text {input }} \cdot C_{\mathrm{CO}_{2} \%} \cdot \frac{44}{12} \\
\mathrm{CH}_{4, \text { release }}=C_{\text {input }} \cdot C_{\text {degraded } \%} \cdot C_{\mathrm{CH}_{4} \%} \cdot \frac{16}{12}
\end{gathered}
$$

where $C_{\text {input }}$ is total carbon content in raw waste $(\mathrm{kg}), \mathrm{C}_{\mathrm{CO} 2 \%}$ is percent of $\mathrm{C}$ converting to $\mathrm{CO}_{2}(\%), \mathrm{C}_{\mathrm{CH} 4 \%}$ is percent of $\mathrm{C}$ converting to $\mathrm{CH}_{4}(\%), C_{\text {degraded } \%}$ is percent of $C_{\text {input }}$ degraded (\%).

$\mathrm{N}_{2} \mathrm{O}$ was calculated based on the total nitrogen input as:

$$
\mathrm{N}_{2} \mathrm{O}_{\text {release }}=N_{\text {input }} \cdot N_{\mathrm{N}_{2} \mathrm{O} \%} \cdot \frac{44}{28}
$$

where $N_{\text {input }}$ is total nitrogen content in raw waste $(\mathrm{kg}), \mathrm{N}_{\mathrm{N} 2 \mathrm{O} \%}$ is percent of $\mathrm{N}$ converting to $\mathrm{N}_{2} \mathrm{O}(\%)$.

\subsubsection{Landfill}

The emission from landfill consists of various gases which are potentially contributed to the amount of global GHGs, in particular $\mathrm{CH}_{4} \cdot \mathrm{CH}_{4}$ was estimated by applying IPCC Waste Model [13]. The model was developed based on first order decay method with the main input of degradable organic carbon (DOC). $\mathrm{CH}_{4}$ generation, in this model, can be simulated by two ways depending on input data; bulk waste or waste by composition. In this study, waste by composition option was chosen and $\mathrm{CH}_{4}$ generation can be simulated as:

$$
\mathrm{CH}_{4} \text { generated }_{T}=\sum_{x} \operatorname{DDOC}_{x, m a_{T-1}}\left(1-e^{-k_{x}}\right) \times F \times \frac{16}{12}
$$

Part of the $\mathrm{CH}_{4}$ generated is oxidized in the cover of the landfill, or can be recovered for energy or flaring. The $\mathrm{CH}_{4}$ actually emitted from the landfill will hence be smaller than the amount generated.

$$
\mathrm{CH}_{4} \text { emission }_{T}=\left(\sum_{x} \mathrm{CH}_{4} \text { generation }_{x, T}-R_{T}\right) \times\left(1-O X_{T}\right)
$$

where $T$ is inventory year, $x$ is waste component, $F \quad$ is fraction of $\mathrm{CH}_{4}$ in generated landfill gas (volume fraction), $k$ is reaction constant $\left(\mathrm{y}^{-1}\right), D D O C_{m a_{T-1}}$ is mass of decomposable DOC accumulated in the landfill at the end of year T-1 $(\mathrm{Gg}), R_{T}$ is recovery $\mathrm{CH}_{4}$ in year $\mathrm{T}(\mathrm{Gg}), O X_{T}$ is oxidation factor in year $\mathrm{T}$ (fraction), $\mathrm{CH}_{4}$ generated $_{T}$ is amount of $\mathrm{CH}_{4}$ generated in year $\mathrm{T}(\mathrm{Gg}), \mathrm{CH}_{4}$ emission $_{T}$ is amount of $\mathrm{CH}_{4}$ emitted to the atmosphere in year $\mathrm{T}(\mathrm{Gg})$.

\section{Results and discussion}

\subsection{MSW generation and its composition}

Generated MSW in MPP was basically a mixed waste which is generated from 9 difference sources. The basic information of population, GDP and waste 
generation from 1994 to 2010 are presented in Table 1 and the distribution of generated waste from the 9 sources is presented in Fig. 1.

Table 1: $\quad$ Population, GDP and amount of disposal waste from 1994 to 2010.

\begin{tabular}{llllllll}
\hline \multirow{2}{*}{ Year } & \multicolumn{2}{l}{ Population $^{\mathrm{a}}[\mathrm{million}]$} & \multicolumn{4}{l}{$\mathrm{GDP}^{\mathrm{b}}$ (Current price) } & \multicolumn{3}{l}{ Amount of waste [tons ${ }^{-1}$ ] } \\
\cline { 2 - 8 } & Cambodia & MPP & $\begin{array}{l}\text { US\$ } \\
\text { Capita }^{-1}\end{array}$ & $\begin{array}{l}\text { Growth } \\
\text { rate [\%] }\end{array}$ & $\mathrm{c}$ & $\mathrm{d}$ & $\mathrm{e}$ \\
\hline 1994 & 9.752 & 0.812 & 247 & 8.2 & - & 14,500 & - \\
1995 & 10.148 & 0.855 & 297 & 20.3 & 136,388 & 14,548 & - \\
1996 & 10.560 & 0.901 & 295 & -1.0 & 143,103 & 15,264 & - \\
1997 & 10.990 & 0.949 & 281 & -4.7 & 142,536 & 15,203 & - \\
1998 & 11.436 & 1.000 & 253 & -9.8 & 169,111 & 18,038 & - \\
1999 & 11.656 & 1.007 & 282 & 11.4 & 191,625 & 20,440 & - \\
2000 & 11.881 & 1.014 & 288 & 2.2 & 219,000 & 20,702 & - \\
2001 & 12.110 & 1.022 & 308 & 7.0 & - & 21,050 & - \\
2002 & 12.344 & 1.029 & 326 & 5.9 & - & 21,367 & - \\
2003 & 12.581 & 1.037 & 345 & 5.6 & - & 240,859 & 253,569 \\
2004 & 12.824 & 1.044 & 389 & 12.8 & - & 227,910 & 261,457 \\
2005 & 12.963 & 1.108 & 454 & 15.7 & - & 266,781 & 283,076 \\
2006 & 13.103 & 1.177 & 513 & 13.0 & - & 324,159 & 328,902 \\
2007 & 13.245 & 1.249 & 575 & 12.0 & - & 343,657 & 343,742 \\
2008 & 13.389 & 1.326 & 739 & 19.8 & - & 361,344 & 355,561 \\
2009 & - & - & 765 & 0.0 & - & 393,141 & - \\
2010 & - & - & 830 & 9.8 & - & 409,335 & - \\
\hline
\end{tabular}

${ }^{\mathrm{a}}[1] ;{ }^{\mathrm{b}}[1-7] ;{ }^{\mathrm{c}}[8] ;{ }^{\mathrm{d}}[3,4] ;{ }^{\mathrm{e}}[15]$

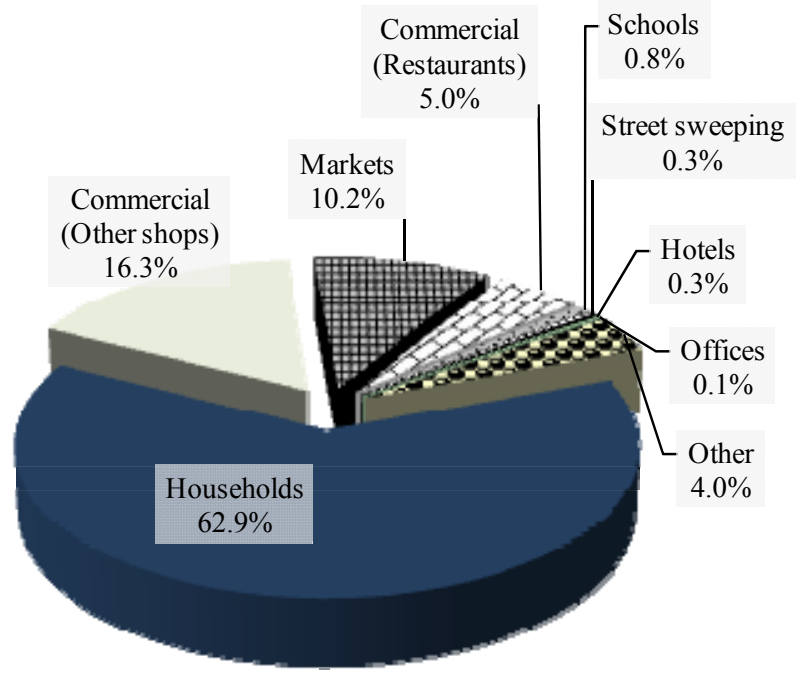

Figure 1: Distribution of MSW in MPP. 
Future MSW generation was predicted based on the available data of the base year 2003. The total amount of forecasted waste generation from 2003 to 2020 is presented in Table 2. The amount of waste generation was predicted to increase significantly from 811.2 tons $\mathrm{d}^{-1}$ in 2003 to 2783.9 tons $^{-1}$ in 2020 . Overall, the predicted results showed higher values than actual data from 2003 to 2010. It was hard to calibrate the predicted results because the available data was the amount of waste collected for disposal, not the amount of generated waste. Basically, the amount of generated waste is bigger than that of disposal waste and their difference depends on collection efficiency. In 2009, around $82.1 \%$ of generated MSW was collected for disposal [14]. This means that the total amount of generated waste should be around 1311.9 tons $\mathrm{d}^{-1}$

Table 2: $\quad$ Forecasted number of waste generation source, waste generation rate, and total waste generation amount 2003-2020.

\begin{tabular}{|c|c|c|c|c|c|c|c|c|}
\hline Sources & Unit & 2003 & 2006 & 2009 & 2012 & 2015 & 2018 & 2020 \\
\hline \multicolumn{9}{|c|}{ Number of waste generation sources } \\
\hline Household waste & $\begin{array}{l}\text { person } \\
\text { (million) }\end{array}$ & 1.037 & 1.177 & 1.439 & 1.637 & 1.835 & 2.018 & 2.127 \\
\hline $\begin{array}{l}\text { Commercial waste } \\
\text { (restaurant) }\end{array}$ & Table & 27808 & 38492 & 45222 & 54013 & 64513 & 77053 & 86741 \\
\hline $\begin{array}{l}\text { Commercial waste } \\
\text { (Other shops) }\end{array}$ & Shop & 33524 & 46404 & 54518 & 65116 & 77773 & 92892 & 104570 \\
\hline Market waste & Stall & 51766 & 71655 & 84184 & 100548 & 120094 & 143439 & 161472 \\
\hline School waste & Student & 385013 & 532936 & 626122 & 747834 & 893205 & 1066835 & 1200959 \\
\hline Hotel waste & Room & 13385 & 18528 & 21767 & 25998 & 31052 & 37089 & 41751 \\
\hline Office waste & Office & 368 & 509 & 598 & 715 & 854 & 1020 & 1148 \\
\hline Street sweeping waste & $\mathrm{km}$ & 56 & 56 & 56 & 56 & 56 & 56 & 56 \\
\hline \multicolumn{9}{|l|}{ Waste generation rate } \\
\hline Household waste & g person $^{-1} d^{-1}$ & 487 & 517 & 553 & 588 & 622 & 658 & 683 \\
\hline $\begin{array}{l}\text { Commercial waste } \\
\text { (restaurant) }\end{array}$ & g table $\mathrm{d}^{-1}$ & 1664 & 1766 & 1891 & 2008 & 2125 & 2248 & 2335 \\
\hline $\begin{array}{l}\text { Commercial waste } \\
\text { (Other shops) }\end{array}$ & g shop ${ }^{-1} d^{-1}$ & 4502 & 4777 & 5114 & 5433 & 5748 & 6082 & 6315 \\
\hline Market waste & $\mathrm{g} \mathrm{stall}^{-1} \mathrm{~d}^{-1}$ & 1823 & 1934 & 2071 & 2199 & 2327 & 2462 & 2557 \\
\hline School waste & g student $t^{-1} d^{-1}$ & 20 & 21 & 22 & 24 & 25 & 26 & 27 \\
\hline Street sweeping waste & $\mathrm{g} \mathrm{km}^{-1} \mathrm{~d}^{-1}$ & 53373 & 53373 & 53373 & 53373 & 53373 & 53373 & 53373 \\
\hline Hotel waste & g room $^{-1} d^{-1}$ & 231 & 245 & 262 & 279 & 295 & 312 & 324 \\
\hline Office waste & g office ${ }^{-1} d^{-1}$ & 3560 & 3778 & 4045 & 4296 & 4546 & 4810 & 4995 \\
\hline \multicolumn{9}{|l|}{ Waste generation amount } \\
\hline Household waste & Tons d $^{-1}$ & 504.8 & 608.1 & 796.1 & 962.4 & 1141.2 & 1328.0 & 1453.0 \\
\hline $\begin{array}{l}\text { Commercial waste } \\
\text { (restaurant) }\end{array}$ & Tons $\mathrm{d}^{-1}$ & 46.3 & 68.0 & 85.5 & 108.5 & 137.1 & 173.2 & 202.5 \\
\hline $\begin{array}{l}\text { Commercial waste } \\
\text { (Other shops) }\end{array}$ & Tons $\mathrm{d}^{-1}$ & 150.9 & 221.7 & 278.8 & 353.7 & 447.1 & 565.0 & 660.4 \\
\hline Market waste & Tons $\mathrm{d}^{-1}$ & 94.3 & 138.6 & 174.3 & 221.2 & 279.5 & 353.2 & 412.9 \\
\hline School waste & Tons $\mathrm{d}^{-1}$ & 7.5 & 11.0 & 13.9 & 17.6 & 22.2 & 28.1 & 32.9 \\
\hline Hotel waste & Tons $\mathrm{d}^{-1}$ & 3.1 & 4.5 & 5.7 & 7.2 & 9.2 & 11.6 & 13.5 \\
\hline Office waste & Tons $\mathrm{d}^{-1}$ & 1.3 & 1.9 & 2.4 & 3.1 & 3.9 & 4.9 & 5.7 \\
\hline Street sweeping waste & Tons $\mathrm{d}^{-1}$ & 3.0 & 3.0 & 3.0 & 3.0 & 3.0 & 3.0 & 3.0 \\
\hline Total & Tons $^{-1}$ & 811.2 & 1056.8 & 1359.7 & 1676.7 & 2043.1 & 2467.0 & 2783.9 \\
\hline
\end{tabular}


(waste disposal $=1077.1$ tons $\mathrm{d}^{-1}$ ) which compares to the predicted value of 1359.7 tons $\mathrm{d}^{-1}$. The forecasted waste generation was hence acceptable and used for further analysis in scenario studies.

The forecasted results revealed that household waste has always made up the biggest portion $(>52.2 \%)$, followed by commercial waste (other shops) $(>18.6 \%)$, market waste $(>11.6 \%)$ and commercial waste (restaurant) $(>5.7 \%)$. The remaining sources including school, hotel, office and street sweeping waste have accounted for less than $1.2 \%$.

Waste composition was categorized into 10 components including paper, rubber/leather, kitchen waste, textile, plastics, grass/wood, metals, bottle/glass, soil/stone and other. In 2003, waste generated from household, market, commercial (other shops), commercial (restaurant), hotel and office contained the biggest portion of kitchen waste $(>35.3 \%)$, followed by either plastics $(>9.9 \%)$ or paper $(>5.2 \%)$, whereas the other components were less significant. On the other hand, school waste contained the biggest portion of plastics $(26.5 \%)$ and paper $(25.0 \%)$, and street sweeping waste contained the biggest portion of soil/stone $(58.3 \%)$. The proportion of waste composition in future generated waste from each source kept the same order. However, the portion of plastic, paper and bottle/glass increased gradually in the future while that of other components decreased slightly. The waste composition forecast, household waste is as a sample, is presented in Table 3.

Table 3: $\quad$ Forecasted household waste composition from 2003 to 2020.

\begin{tabular}{lrrrrrrr}
\hline Composition & 2003 & 2006 & 2009 & 2012 & 2015 & 2018 & 2020 \\
\hline Paper & 5.23 & 5.47 & 5.75 & 6.01 & 6.26 & 6.51 & 6.69 \\
Rubber /Leather & 0.14 & 0.13 & 0.13 & 0.13 & 0.13 & 0.13 & 0.12 \\
Kitchen Waste & 61.45 & 60.56 & 59.51 & 58.56 & 57.64 & 56.70 & 56.06 \\
Textile & 2.57 & 2.53 & 2.49 & 2.45 & 2.41 & 2.37 & 2.35 \\
Plastic & 17.83 & 18.65 & 19.62 & 20.51 & 21.36 & 22.23 & 22.82 \\
Grass /Wood & 8.46 & 8.34 & 8.20 & 8.06 & 7.94 & 7.81 & 7.72 \\
Metals & 0.67 & 0.66 & 0.65 & 0.64 & 0.63 & 0.62 & 0.61 \\
Bottles /Glass & 0.81 & 0.85 & 0.89 & 0.93 & 0.97 & 1.01 & 1.04 \\
Soil /Stone & 1.04 & 1.03 & 1.01 & 0.99 & 0.98 & 0.96 & 0.95 \\
Others & 1.80 & 1.77 & 1.74 & 1.71 & 1.69 & 1.66 & 1.64 \\
\hline Total & 100 & 100 & 100 & 100 & 100 & 100 & 100 \\
\hline
\end{tabular}

\subsection{Green house gases emission}

The GHGs emission from both composting and landfill were estimated. The GHGs emission from composting was attributed to two gases; $\mathrm{CH}_{4}$ and nitrous oxide $\left(\mathrm{N}_{2} \mathrm{O}\right)$, whereas only $\mathrm{CH}_{4}$ was considered to contribute to GHGs emission from landfill. $\mathrm{CO}_{2}$ emitted from both composting and landfill was not accounted for net GHGs emission as a result of its biogenic origin [13]. To compare the quantitative GHGs emission, all gas components were converted to $\mathrm{CO}_{2}$ equivalent $\left(\mathrm{CO}_{2} \mathrm{eq}\right) ; \mathrm{CH}_{4}$ is 21 times higher than $\mathrm{CO}_{2}$ and $\mathrm{N}_{2} \mathrm{O}$ is 310 times higher than $\mathrm{CO}_{2}$. 
In composting system, the percent of carbon converted to $\mathrm{CO}_{2}$ was reported to be in the range $50-60 \%$ of input carbon [12]. The percent of total carbon degraded was assumed to be in the range $66-84 \%$ based on hemicelluloses and fiber degradation rate during composting period [16]. The percent of carbon converted to $\mathrm{CH}_{4}$ was in the range $0.8-2.5 \%$ of degraded carbon [17]. Based on the above criteria, GHGs emission from each scenario is presented in Table 4.

Table 4: $\quad$ Green house gases emission from composting 2003-2020.

\begin{tabular}{|c|c|c|c|c|c|c|c|}
\hline Scenarios & 2003 & 2006 & 2009 & 2012 & 2015 & 2018 & 2020 \\
\hline \multicolumn{8}{|c|}{$\mathrm{CO}_{2}$ emission rate $\left[\right.$ Ton $\left.\mathrm{d}^{-1}\right]$} \\
\hline Scenario 1 & 0.00 & 0.00 & 0.00 & 0.00 & 0.00 & 0.00 & 0.00 \\
\hline Scenario 2 & 155.45 & 181.90 & 229.96 & 269.13 & 309.20 & 348.16 & 372.37 \\
\hline Scenario 3 & 41.10 & 58.49 & 70.84 & 86.78 & 106.02 & 129.36 & 147.61 \\
\hline Scenario 4 & 255.33 & 324.89 & 404.39 & 484.28 & 573.71 & 673.04 & 744.74 \\
\hline \multicolumn{8}{|c|}{$\mathrm{CH}_{4}$ emission rate [Ton $\mathrm{d}^{-1}$ ] } \\
\hline Scenario 1 & 0.00 & 0.00 & 0.00 & 0.00 & 0.00 & 0.00 & 0.00 \\
\hline Scenario 2 & 1.21 & 1.41 & 1.78 & 2.09 & 2.40 & 2.70 & 2.89 \\
\hline Scenario 3 & 0.32 & 0.45 & 0.55 & 0.67 & 0.82 & 1.00 & 1.15 \\
\hline Scenario 4 & 1.98 & 2.52 & 3.14 & 3.76 & 4.45 & 5.22 & 5.78 \\
\hline \multicolumn{8}{|c|}{$\mathrm{N}_{2} \mathrm{O}$ emission rate $\left[\right.$ Ton $\left.\mathrm{d}^{-1}\right]$} \\
\hline Scenario 1 & 0.00 & 0.00 & 0.00 & 0.00 & 0.00 & 0.00 & 0.00 \\
\hline Scenario 2 & 0.02 & 0.03 & 0.04 & 0.04 & 0.05 & 0.05 & 0.06 \\
\hline Scenario 3 & 0.01 & 0.01 & 0.01 & 0.02 & 0.02 & 0.02 & 0.03 \\
\hline Scenario 4 & 0.04 & 0.05 & 0.06 & 0.08 & 0.09 & 0.11 & 0.12 \\
\hline \multicolumn{8}{|c|}{ GHG emission rate* $\left(\mathrm{CH}_{4} \times 21+\mathrm{N}_{2} \mathrm{O} \times 310\right)\left[\mathrm{Ton} \mathrm{CO}_{2} \mathrm{eq} \mathrm{d}^{-1}\right]$} \\
\hline Scenario 1 & 0.00 & 0.00 & 0.00 & 0.00 & 0.00 & 0.00 & 0.00 \\
\hline Scenario 2 & 32.81 & 38.39 & 48.53 & 56.80 & 65.26 & 73.48 & 78.59 \\
\hline Scenario 3 & 9.02 & 12.84 & 15.55 & 19.05 & 23.27 & 28.39 & 32.40 \\
\hline Scenario 4 & 54.23 & 69.05 & 85.94 & 102.93 & 121.96 & 143.12 & 158.41 \\
\hline \multicolumn{8}{|c|}{ GHG emission per year [Ton $\left.\mathrm{CO}_{2} \mathrm{eq}\right]$} \\
\hline Scenario 1 & 0.00 & 0.00 & 0.00 & 0.00 & 0.00 & 0.00 & 0.00 \\
\hline Scenario 2 & 11974.95 & 14012.45 & 17714.71 & 20732.82 & 23819.01 & 26820.78 & 28685.53 \\
\hline Scenario 3 & 3292.80 & 4685.92 & 5674.53 & 6952.04 & 8492.80 & 10362.59 & 11824.57 \\
\hline Scenario 4 & 19793.77 & 25204.66 & 31367.02 & 37569.26 & 44517.16 & 52239.58 & 57817.90 \\
\hline \multicolumn{8}{|c|}{ Cumulative GHG emission [Ton $\left.\mathrm{CO}_{2} \mathrm{eq}\right]$} \\
\hline Scenario 1 & 0.00 & 0.00 & 0.00 & 0.00 & 0.00 & 0.00 & 0.00 \\
\hline Scenario 2 & 11974.95 & 51212.64 & 100711.32 & 159884.69 & 228251.91 & 305752.39 & 362208.83 \\
\hline Scenario 3 & 3292.80 & 15829.94 & 32334.88 & 51868.02 & 75739.20 & 104877.09 & 127771.89 \\
\hline Scenario 4 & 19793.77 & 88917.37 & 178029.94 & 284415.47 & 410842.66 & 559669.00 & 672471.80 \\
\hline
\end{tabular}

*The conversion of $\mathrm{CH}_{4}$ and $\mathrm{N}_{2} \mathrm{O}$ to $\mathrm{CO}_{2}$ equivalent is based on the global warming potential of each gas, e.g. $\mathrm{CH}_{4}$ is 21 times and $\mathrm{N}_{2} \mathrm{O}$ is 310 times higher than $\mathrm{CO}_{2}$.

GHGs emission from landfill was estimated by IPCC Waste Model. The model was run with the default values of DOC of each waste component and with the default values of reaction constant in Moist and Wet Tropical condition. The detail input parameter's values for the model are presented in Table 5. The total $\mathrm{CH}_{4}$ emission was estimated and accumulated until 60 years after the closure of the landfill. The cumulative GHGs emission from each scenario is presented in Fig. 2. 
Table 5: $\quad$ Input parameter values for IPCC Waste Model.

\begin{tabular}{|c|c|c|c|c|}
\hline Parameter & Symbol & Unit & Value & Remark \\
\hline Degradable Organic Carbon & $D O C$ & & & $\begin{array}{l}\text { Fraction of DOC in waste } \\
\text { composition (Wet basis) }\end{array}$ \\
\hline Food waste & & - & 0.15 & - \\
\hline Garden & & - & 0.2 & - \\
\hline Paper & & - & 0.4 & - \\
\hline Wood and Straw & & - & 0.43 & - \\
\hline Textiles & & - & 0.24 & - \\
\hline Methane Generation Rate Constant & $k$ & & & Moist and Wet Tropical \\
\hline Food waste & & $y^{-1}$ & 0.4 & - \\
\hline Garden & & $y^{-1}$ & 0.17 & - \\
\hline Paper & & $y^{-1}$ & 0.07 & - \\
\hline Wood and Straw & & $y^{-1}$ & 0.035 & - \\
\hline Textiles & & $\mathrm{y}^{-1}$ & 0.07 & - \\
\hline Fraction of DOC & $D O C_{f}$ & - & 0.5 & Fraction of DOC that can decompose \\
\hline Fraction of Methane & $F$ & - & 0.5 & $\begin{array}{l}50 \% \text { by volume of } \mathrm{CH}_{4} \text { in the } \\
\text { generated landfill gas }\end{array}$ \\
\hline Methane Correction Factor & $M C F$ & - & 0.8 & $\begin{array}{l}\text { Unmanaged-deep }(>5 \mathrm{~m} \text { waste }) \text { and } / \text { or } \\
\text { high water table }\end{array}$ \\
\hline Oxidation Factor & $O X$ & - & 0 & $\begin{array}{l}\text { Managed, unmanaged and } \\
\text { uncategorized landfill }\end{array}$ \\
\hline $\mathrm{CH}_{4}$ Recovery & $R$ & - & 0 & No gas collection, No flaring \\
\hline Delay Time & - & months & 6 & $\begin{array}{l}\mathrm{CH}_{4} \text { start to produce after } 6 \text { months } \\
\text { of waste deposition }\end{array}$ \\
\hline
\end{tabular}

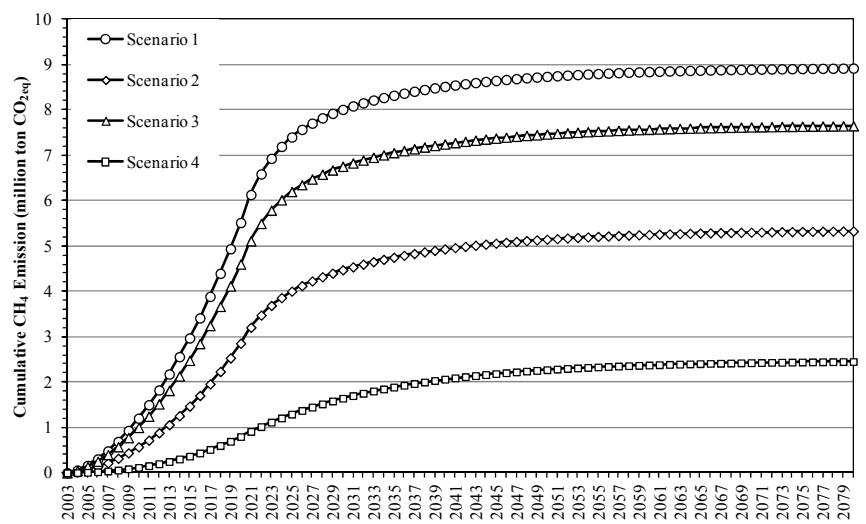

Figure 2: $\quad$ Cumulative $\mathrm{CH}_{4}$ emission from landfill (waste disposal by 2020).

The total GHGs emission from landfill (from 2003 to 2080; landfill received waste until 2020) and composting (from 2003 to 2020) is presented in Fig 3. The results revealed that, based on current MSW management, total GHGs emission from generated waste from 2003 to 2020 would be 8.92 million ton $\mathrm{CO}_{2 \text { eq }}$. However, this amount could be reduced significantly by recycling organic waste through composting. Recycling organic waste from household waste alone (S2) could reduce $36.2 \%$ of GHGs emission to the atmosphere, whereas around $12.8 \%$ and $65.0 \%$ can be reduced if organic waste was recycled in accordance with S3 and S4 compared with S1, respectively. These percent reductions reflect the amount of GHGs reduction of 3.23, 1.14 and 5.79 million tons $\mathrm{CO}_{2}$ eq from the respective $\mathrm{S} 2, \mathrm{~S} 3$ and $\mathrm{S} 4$. 


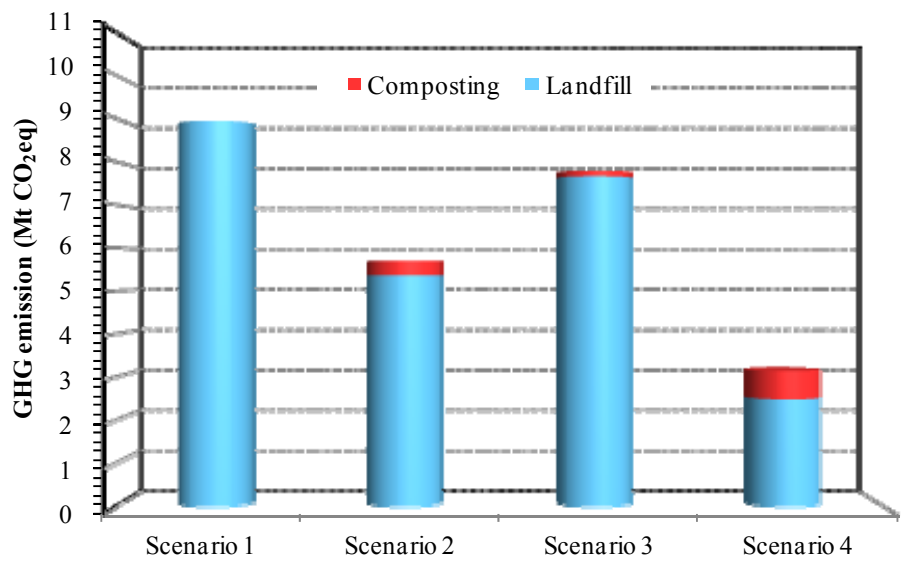

Figure 3: Total GHGs emission from each scenario.

Organic waste recycling gave better benefit than landfill. However, it is important to carefully consider the difficulties in its implementation. In MPP, although organic fraction in generated waste was the largest portion, the nuisance materials (plastics) made composting difficult. Plastics, hence, need removing from the raw waste before composting. Plastics separation can be carried out before waste discharge (source separation) or after waste discharge (separation before composting). The most efficient, easy and economical ways to separate plastic waste is source separation. Therefore, it is strongly recommended that simple separation activities should be introduced to the residents in MPP. The simplest way is to separate organic, plastic and unburnable waste. Organic waste can be used as resource for composting, plastic waste can be used for RDF production, or direct incineration for energy recovery, and unburnable waste is disposed of at landfill. It is also important to make sure that collection and transport of the separated waste can be performed by the current private firm.

\section{Conclusion}

The study was conducted in MPP, capital city of Cambodia, to gain an insight into benefit of composting over landfill on MSWM. In this study, future waste generation was forecasted from 2003 to 2020 and 4 scenarios of organic waste recycling via composting were carried out, with the main focus on GHGs mitigation. MSW generation in MPP increased significantly from about 0.24 million ton in 2003 to 0.41 million ton in 2010 and was projected to reach 1.02 million tons in 2020. Organic waste recycling via composting could significantly contribute to the solution of improper waste management and environmental impacts. Composting could minimize the GHGs emission of about 36.2, 12.8 and $65.0 \%$ compared with landfill when organic waste was recycled in accordance with scenario S2, S3 and S4, respectively. Hence, it is strongly recommended that MPP should start to prepare a strategic recycling plan along with modification of discharge and collection regulations. 


\section{References}

[1] MoP (Ministry of Planning), Statistical yearbook of Cambodia. National Institute of Statistics, Phnom Penh, Cambodia, 2008.

[2] Kamal, U., National GHG inventories and the war forward. Greenhouse gas Inventory Office of Japan, the $8^{\text {th }}$ workshop on GHG inventories in Asia, 2010 Online. http://www-gio.nies.go.jp/wgia/wg8/pdf/1-1_kamal_uy.pdf

[3] MoE (Ministry of Environment), State of environment report. Ministry of Environment, Phnom Penh, Cambodia, 2004.

[4] Sarun, S., personal communication, 10 May 2009, Chief of Solid Waste Management, Department of Environmental Pollution Control, Ministry of Environment, Cambodia.

[5] JICA, The study on solid waste management in the municipality of Phnom Penh in the Kingdom of Cambodia, Final report, Main report. Phnom Penh, Cambodia, 2005.

[6] UNDP-MoE, Assessment of greenhouse gas mitigation technologies for non-energy sector in Cambodia, Final report. United Nation Framework Convention on Climate Change, CMB/97/G31, 2003 Online. http://unfccc.int/ttclear/pdf/TNA/Cambodia/Cambodia-2.pdf

[7] MoP, NIS National Accounts, Bulletin 2011. National Institute of Statistic, Database Caminfo v4.1, 2011 Online. http://nd.nis.gov.kh/caminfo/

[8] Kum, V., Sharp, A. and Harnpornchai, N., Improving the solid waste management in Phnom Penh city: A strategic approach. Waste Management, 25(1), pp. 101-109, 2005.

[9] MoIAC, Population projection for Cambodia. MoIAC, Janpan, 2011 Online. http://www.stat.go.jp/info/meetings/cambodia/pdf/rp12_ch10.pdf

[10] ADB, Southeast Asia. ADB publication, 2009 Online. http://www.adb.org/documents/books/ado/2009/southeast-asia.pdf

[11] ADB, Asian development bank and Cambodia, Fact sheet. ADB, 2010 Online. http://www.adb.org/Documents/Fact Sheets/CAM.pdf

[12] Boldrin, A., Andersen, K.J., MØller, J., Christensen, H.T. and Favoino, E., Composting and compost utilization: accounting of greenhouse gases and global warming contributions. Waste Management \& Research, 27(8), pp. 800-812, 2009.

[13] IPCC, 2006 IPCC guidelines for national greenhouse gas inventories, volume 5, Waste. IPCC, 2006 Online. http://www.ipccnggip.iges.or.jp/public/2006gl/vol5.html

[14] Hun, S., personal communication, 10 May 2009, Sub-Head Operation Office, CINTRI, Cambodia.

[15] JICA, Project on the strengthening of solid waste management for the municipality of Phnom Penh, final report. Phnom Penh, Cambodia, 2008.

[16] Gomes, P.A., Nunes, I.M., Vitoriano, C.C. and Pedrosa, E., Co-composting of biowaste and poultry waste. ISWA, Italy, Publication, 2009 Online. http://www.iswa.it/materiali/iswa apesb 2009/1-209_FP.pdf

[17] Amlinger, F., Peyr, S. and Cuhls, C., Green house gas emissions from composting and mechanical biological treatment. Waste Management \& Research, 26(1), pp. 47-60, 2008. 